\title{
Effect of Some Medical Plant Extracts on Metabolism of Leishmania tropica Promastigotes In vitro
}

\author{
Saeed $\mathrm{BQ}^{1 *}$, Hassan $\mathrm{HF}^{2}$ and Arteen $\mathrm{HI}^{3}$
}

${ }^{1}$ Department of Health and Medical Sciences, Community College, University of Sharjah, Sharjah, UAE

${ }^{2}$ Department of Biology, College of Science, University of Kirkuk, Kirkuk, Iraq

${ }^{3}$ Department of Biology, College of Science, University of Mosul, Mosul, Iraq

\begin{abstract}
The study included the inhibition effect of Equisetum arvense and Urtica piluifera extracts dissolved in cold and hot water, on the growth of Leishmania tropica. promastigotes, and the effect of these extract on metabolism activates (Total protein, carbohydrates and nucleic acids) of Leishmania tropica. Promastigotes.

The inhibitory concentration of $50 \%$ of the promastigotes (IC50) at the log phase (96) hrs was $1.5 \mu \mathrm{g} / \mathrm{ml}$ of Equisetum arvense and $1.5 \mathrm{\mu g} / \mathrm{ml}$ of Urtica piluifera extracts dissolved in cold and hot water.

The results revealed, that these extracts were studied has inhibitory effect $L$. tropica. promastigotes number, the number of $L$. tropica. reduced gradually when using 0.5 to $2.5 \mu \mathrm{g} / \mathrm{ml}$ concentrations of extracts. Moreover, these extracts were studied has inhibitory effect on total Proteins, Carbohydrates and Nucleic acids. The results of chemical analysis of the plants has highly effect on total protein, and lees effect on total carbohydrates of cell membrane, Moreover, the extract was effect on total Nucleic acids of Leishmania tropica. promastigotes after 96 hrs of cultivation.
\end{abstract}

Keywords: Lieshmania tropica; Equisetum arvense; Urtica piluifera Treatment; Proteins; Carbohydrates; Nucleic acid

\section{Introduction}

Leishmaniasis is a disease caused by hemoflagellate protozoa species of the genus Leishmania [1]. The reservoirs of the disease are rodents, dogs, sanguine marsupials and other wild animals. The disease is transmitted by mosquitoes of the genera Lutzomyia and Phlebotomus. According to the World Health Organization, 88 countries are affected by leishmaniasis, with approximately 350 million people at risk. Comprehending 12 million infected cases, the incidence is increasing worldwide with 1-2 million new cases registered annually, despite efforts being made to fight the disease [2]. Leishmaniasis encompasses three clearly distinguishable clinical manifestations: generalized visceral infection (visceral leishmaniasis or "Kala-azar"), cutaneous leishmaniasis (oriental button), and mucocutaneous leishmaniasis (ulceration of the skin and hyper-development of the mucous membrane) [3].

Leishmaniasis can be controlled mainly by vector and reservoir control and infected case management. The first two approaches are either impractical or expensive, leaving only the case control as the most effective strategy [2].

The best drug for the treatment of leishmaniasis is the pentavalent antimonies, which have been in use for more than 50 years. High failure rates and relapses are observed, particularly in treating co-infected patients, using these drugs [4].

The chemotherapy of this disease has been undermined by resistance, variable efficacy between strains or species, toxicity, parenteral administration, and requirement for long courses of administration. There is an urgent need for new chemotherapeutic drugs for the treatment of these diseases which mainly affect people in developing countries. Extensive studies have shown that medicinal plants of several regions of the world contain compounds active against protozoa [5].
The current study was undertaken to of Equisetum arvense and Urtica piluifera extracts dissolved in cold and hot water, used for the treatment of Leishmania tropica. promastigotes effect on growth or on change in metabolism of parasite

\section{Materials and Methods}

\section{Leishmania tropica. promastigotes}

MHOM/IQ/1992/MREC3 Leishmania tropica stock culture was used. The culture was obtained from the College of Medicine ALNahreen University, which has been characterized using isoenzyme method according to AL-Jeboori and Evans [6]. The obtained culture was cultivated in Tobie's medium [7]. The parasites were checked under the microscope for flagella motility as an indication of viability before each experiment.

\section{Collection of plants}

The aerial parts of Equisetum arvense and Urtica piluifera were collected from Tikrit and Mousel city in Iraq.

\section{Preparation of extracts}

The plant parts were cleaned with water to remove dirt, then placed in a glass with diluted chlorine (1\%) for one minute, the plant

*Corresponding author: Saeed BQ, Department of Health and Medical Sciences, Community College, University of Sharjah, Sharjah, UAE, Tel: 065057914; E-mail: bsaeed@sharjah.ac.ae

Received May 24, 2014; Accepted September 19, 2014; Published September 21, 2014

Citation: Saeed BQ, Hassan HF, Arteen HI (2014) Effect of Some Medical Plant Extracts on Metabolism of Leishmania tropica Promastigotes In vitro. J Med Microb Diagn 3: 165. doi:10.4172/2161-0703.1000165

Copyright: (c) 2014 Saeed BQ, et al. This is an open-access article distributed under the terms of the Creative Commons Attribution License, which permits unrestricted use, distribution, and reproduction in any medium, provided the original author and source are credited. 
parts were dried at room temperature, Then kept in free of moisture conditions in paper envelopes [8].

The plant extract prepared as, A volume of $(0.25 \mathrm{~g})$ from each extract was dissolved in $5 \mathrm{ml}$ of hot and cold water to produce a final concentration of $50 \mathrm{mg} / \mathrm{ml}$ which was used as a stock concentration in providing next dilutions $(0.5,1.0,1.5,2.0$ and 2.5$) \mu \mathrm{g} / \mathrm{ml}$ all extracts were sterilized by filtration through a $0.45 \mu \mathrm{m}$ membrane filter [9].

\section{Cultivation and estimating numbers of parasites}

$1.9 \mathrm{ml}$ of liquid phase was added to McCantry vials containing $5 \mathrm{ml}$ solid phase slants, $0.1 \mathrm{ml}$ of Leishmania promastigotes inoculums was taken from stock culture during logarithmic phase, so that the initial density of the organism was $2 \times 10^{5} / \mathrm{ml}$, then the number of organisms of new culture incubated at $26^{\circ} \mathrm{C}$ for 4 days, was counted directly using a haemocytometer.

\section{Estimation of total proteins, carbohydrates, and nucleic acids (DNA and RNA)}

The Total Protein quantitative determination estimated by Lowry's Method [10], while Herbert method [11] were carried out to estimate total carbohydrates, Schneider's method $[12,13]$ was used for quantitative estimation of total Nucleic acids, DNA and RNA in treated and untreated parasites.

\section{Results}

The results of effect of $E$. arvense on $L$. tropica promastigotes are presented in Table 1 . The number of $L$. tropica decreased gradually by using 0.5 to $2.5 \mu \mathrm{g} / \mathrm{ml}$ concentrations of $E$. Arvense extract, Moreover, the extracts effect on number and time of generation, an inverse relationship could be established between concentration of the extract and growth mean of the parasite. Inhibitory concentration of $50 \%$ of promastigotes (IC50) was $1.5 \mu \mathrm{g} / \mathrm{ml}$, whereas at logarithmic phase (96 hrs of cultivation).

Table 2 show the number of Leishmania tropica. promastigotes decreased gradually by using different concentrations 0.5 to $2.5 \mu \mathrm{g} / \mathrm{ml}$ of Urtica piluifera extract dissolve in cold water from 47.4 at $24 \mathrm{~h}$ to 15.6 after 96 hrs of cultivation, Moreover, Inhibitory concentration of $50 \%$ of promastigotes $\left(\mathrm{IC}_{50}\right.$ ) was $1.0 \mu \mathrm{g} / \mathrm{ml}$, whereas at logarithmic phase (96 hrs of cultivation).

Table 3 shows the inhibitory effects of different concentrati ons of the $U$. Piluifera dissolve in hot water 0.5 to $2.5 \mu \mathrm{g} / \mathrm{ml}$, on Leishmania growth in comparison with control group, during different time intervals. Relatively all concentrations used demonstrated significant inhibitory effects against Leishmania promastigotes. An inverse relationship could be established between concentration of the extract and growth mean of the parasite. Inhibitory concentration of $50 \%$ of

\begin{tabular}{|c|c|c|c|c|c|c|c|c|}
\hline \multirow{2}{*}{$\begin{array}{c}\text { Hours } \\
\text { Treatment } / \mu \mathrm{g} / \mathrm{ml}\end{array}$} & \multicolumn{2}{|c|}{24} & \multicolumn{2}{|c|}{48} & \multicolumn{2}{|c|}{72} & \multicolumn{2}{|c|}{96} \\
\hline & Mean +/- SD* & Growth\% & Mean +/- SD* & Growth\% & Mean +/- SD* & Growth\% & Mean +/- SD* & Growth\% \\
\hline Control & $0 \pm 1.10 a$ & 100 & $0.005 \pm 3.60 a$ & 100 & $0.025 \pm 7.25 a$ & 100 & $0.011 \pm 12.53 a$ & 100 \\
\hline 0.5 & $0.005 \pm 0.88 c$ & 80 & $0.028 \pm 2.16 c$ & 60 & $0.022 \pm 6.55 c$ & 90.3 & $0.022 \pm 11.91 c$ & 95 \\
\hline 1 & $0.023 \pm 0.75 d$ & 68.1 & $0.025 \pm 1.66 d$ & 46.1 & $0.055 \pm 4.80 d$ & 66.2 & $0.044 \pm 7.70 d$ & 61.4 \\
\hline 1.5 & $0.005 \pm 0.53 e$ & 68.1 & $0.014 \pm 1.60 \mathrm{e}$ & 44.4 & $0.027 \pm 3.52 e$ & 48.5 & $0.025 \pm 5.82 e$ & 46.4 \\
\hline 2 & $0.022 \pm 0.43 f$ & 48.1 & $0.021 \pm 1.050 f$ & 29.1 & $0.014 \pm 1.15 f$ & 15.8 & $0.011 \pm 4.12 f$ & 32.8 \\
\hline 2.5 & $0.006 \pm 0.27 \mathrm{~g}$ & 39.0 & $0.01 \pm 0.90 \mathrm{~g}$ & 25 & $0.06 \pm 1.05 \mathrm{~g}$ & 14.1 & $0.057 \pm 2.03 \mathrm{~g}$ & 16.2 \\
\hline
\end{tabular}

*Three replicates were used for each treatment Mean and Standard Deviation were multiplied $\mathrm{x} 105$

Different letters refers to presence of significant differences between treatments at $P \leq 0.05$, according to Duncan's test [13].

Table 1: Effect of different concentrations of $E$. arvense on numbers of Leishmania tropica. promastigotes at different time intervals.

\begin{tabular}{|c|c|c|c|c|c|c|c|c|}
\hline \multirow{2}{*}{$\begin{array}{c}\text { Hours } \\
\text { Treatment } / \mu \mathrm{g} / \mathrm{ml}\end{array}$} & \multicolumn{2}{|c|}{24} & \multicolumn{2}{|c|}{48} & \multicolumn{2}{|c|}{72} & \multicolumn{2}{|c|}{96} \\
\hline & Mean +/- SD* & Growth\% & Mean +/- SD* & Growth\% & Mean +/- SD* & Growth\% & Mean +/- SD* & Growth\% \\
\hline Control & $0.038 \pm 1.18 a$ & 100 & $0.028 \pm 4.13 a$ & 100 & $0.014 \pm 8.74 a$ & 100 & $\begin{array}{c}0.009 \pm \\
20.00100 \mathrm{a}\end{array}$ & \\
\hline 0.5 & $0.030 \pm 0.95 c$ & 80.5 & $0.011 \pm 3.77 c$ & 91.2 & $0.005 \pm 7.05 \mathrm{c}$ & 80.6 & $0.26 \pm 16.08 c$ & 80.4 \\
\hline 1 & $0.018 \pm 0.91 d$ & 77.1 & $0.009 \pm 1.85 d$ & 44.7 & $0.022 \pm 4.31 d$ & 49.3 & $0.43 \pm 10.20 d$ & 51 \\
\hline 1.5 & $0.009 \pm 0.81 \mathrm{e}$ & 68.6 & $0.30 \pm 1.37 e$ & 33.1 & $0.001 \pm 2.30 \mathrm{e}$ & 26.3 & $0.038 \pm 7.14 \mathrm{e}$ & 35.7 \\
\hline 2 & $0.002 \pm 0.65 f$ & 55 & $0.007 \pm 1.12 f$ & 27.1 & $0.005 \pm 2.07 f$ & 23.6 & $0.008 \pm 4.93 f$ & 24.6 \\
\hline 2.5 & $0.002 \pm 0.65 f$ & 47.4 & $0.071 \pm 0.89 g$ & 21.5 & $0.057 \pm 1.34 \mathrm{~g}$ & 15.3 & $0.057 \pm 3.13 g$ & 15.6 \\
\hline
\end{tabular}

*Three replicates were used for each treatment Mean and Standard Deviation were multiplied $\times 105$

Different letters refers to presence of significant differences between treatments at $P \leq 0.05$, according to Duncan's test [13].

Table 2: Effect of different concentrations of $U$. Piluifera dissolve in cold water on numbers of Leishmania tropica. promastigotes at different time intervals.

\begin{tabular}{|c|c|c|c|c|c|c|c|c|}
\hline \multirow{2}{*}{$\begin{array}{c}\text { Hours } \\
\text { Treatment } / \mu \mathrm{g} / \mathrm{ml}\end{array}$} & \multicolumn{2}{|c|}{24} & \multicolumn{2}{|c|}{48} & \multicolumn{2}{|c|}{72} & \multicolumn{2}{|c|}{96} \\
\hline & Mean +/- SD* & Growth\% & Mean +/- SD* & Growth\% & Mean +/- SD* & Growth\% & Mean +/- SD* & Growth\% \\
\hline Control & $0.076 \pm 1.06 a$ & 100 & $0.12 \pm 2.40 a$ & 100 & $0.43 \pm 4.80 a$ & 100 & $0.076 \pm 10.33 a$ & 100 \\
\hline 0.5 & $0.003 \pm 0.87 c$ & 82 & $0.006 \pm 2.10 c$ & 87.5 & $0.028 \pm 4.13 c$ & 86 & $0.008 \pm 9.28 b$ & 89.8 \\
\hline 1 & $0.009 \pm 0.80 \mathrm{~d}$ & 75.4 & $0.014 \pm 1.03 d$ & 42.9 & $0.086 \pm 2.40 d$ & 50 & $0.016 \pm 5.00 c$ & 48.4 \\
\hline 1.5 & $0.011 \pm 0.60 \mathrm{e}$ & 56.6 & $0.002 \pm 0.89 e$ & 37 & $0.26 \pm 1.33 e$ & 27.7 & $0.004 \pm 2.95 d$ & 28.5 \\
\hline 2 & $0.028 \pm 0.63 e$ & 59.4 & $0.004 \pm 0.69 f$ & 28.7 & $0.025 \pm 1.06 f$ & 22 & $0.115 \pm 2.36 \mathrm{e}$ & 22.8 \\
\hline 2.5 & $0.028 \pm 0.43 f$ & 40.5 & $0.006 \pm 0.56 \mathrm{~g}$ & 23.3 & $0.005 \pm 0.90 \mathrm{~g}$ & 18.7 & $0.009 \pm 1.26 f$ & 12.1 \\
\hline
\end{tabular}

*Three replicates were used for each treatment Mean and Standard Deviation were multiplied $\times 105$

Different letters refers to presence of significant differences between treatments at $P \leq 0.05$, according to Duncan's test [13].

Table 3: Effect of different concentrations of $U$. Piluifera dissolve in hot water on numbers of Leishmania tropica. promastigotes at different time intervals. 


\begin{tabular}{|c|c|c|c|c|c|}
\hline Treatment & $\mathrm{IC} 50(\mu \mathrm{g} / \mathrm{ml})$ & Total Protein & Total Protein \% & \multicolumn{2}{|c|}{$\%$ variation } \\
\hline Control & --- & $2.8 \pm 437.33 a$ & 100 & --- & --- \\
\hline E. arvense & 1.5 & $0.175 \pm 403.33 b$ & 92.2 & --- & 7.8 \\
\hline U. Piluifera dissolve in Cold water & 1 & $0.005 \pm 372.67 c$ & 85.2 & --- & 14.8 \\
\hline U. Piluifera dissolve in Cold and Hot water & 1 & $0.05 \pm 346.0 \mathrm{~d}$ & 79.1 & --- & 20.9 \\
\hline
\end{tabular}

Table 4: Effect of IC50 of E. arvense and U. Piluifera dissolve in Cold and Hot water on the amount of total protein ( $\mu \mathrm{g} / \mathrm{ml})$ of $L$. tropica. promastigotes at log-phase (96 hrs).

\begin{tabular}{|c|c|c|c|c|c|}
\hline Treatment & $\mathrm{IC} 50(\mu \mathrm{g} / \mathrm{ml})$ & Total Protein & Total Protein \% & \multicolumn{2}{|c|}{$\%$ variation } \\
\hline Control & --- & $5.61 \pm 165.0 a$ & 100 & --- & --- \\
\hline E. arvense & 1.5 & $2.38 \pm 152.5 b$ & 92.2 & --- & 7.6 \\
\hline U. Piluifera dissolve in Cold water & 1 & $2.88 \pm 137.3 c$ & 83.2 & --- & 16.8 \\
\hline U. Piluifera dissolve in Cold and Hot water & 1 & $0.46 \pm 135.0 \mathrm{~d}$ & 81.8 & --- & 18.2 \\
\hline
\end{tabular}

Table 5: Effect of IC50 of E. arvense and U. Piluifera dissolve in Cold and Hot water on the amount of total Carbohydrates ( $\mu$ g/ml) of $L$. tropica. promastigotes at log-phase (96 hrs).

\begin{tabular}{|c|c|c|c|c|c|c|c|c|c|c|}
\hline Treatment & IC50 $(\mu \mathrm{g} / \mathrm{ml})$ & $\begin{array}{c}\text { DNA } \\
\mu \mathrm{g} / \mathrm{ml} \text { Mean } \\
+/-\mathrm{SD}^{*}\end{array}$ & $\begin{array}{c}\% \\
\text { Concentration }\end{array}$ & $\begin{array}{c}\% \\
\text { Decrease }\end{array}$ & $\begin{array}{c}\text { RNA } \\
\mu \mathrm{g} / \mathrm{ml} \text { Mean } \\
+/-\mathrm{SD}^{*}\end{array}$ & $\begin{array}{c}\% \\
\text { Concentration }\end{array}$ & $\begin{array}{c}\% \\
\text { Decrease }\end{array}$ & $\begin{array}{l}\text { Total Nucleic acid } \\
\text { (DNA \& RNA) } \\
\mu \mathrm{g} / \mathrm{ml} \text { Mean +/- SD* }\end{array}$ & $\begin{array}{c}\% \\
\text { Concentration }\end{array}$ & $\%$ Decrease \\
\hline Control & - & $1.73 \pm 33.0 a$ & 100 & -- & $0.1 \pm 74.0 \mathrm{a}$ & 100 & -- & $0.57 \pm 107.0 \mathrm{a}$ & 100 & -- \\
\hline E. arvense & 1.5 & $2.8 \pm 30.0 \mathrm{~b}$ & 90.9 & 9.1 & $2.7 \pm 50.5 b$ & 67.5 & 32.5 & $2.8 \pm 80.0 \mathrm{~b}$ & 74.7 & 25.3 \\
\hline $\begin{array}{c}\text { U. Piluifera dissolve in Cold } \\
\text { water }\end{array}$ & 1 & $2.8 \pm 23.0 \mathrm{c}$ & 69.6 & 30.4 & $2.7 \pm 50.0 c$ & 67.5 & 32.5 & $3.2 \pm 73.0 \mathrm{c}$ & 68.2 & 31.8 \\
\hline $\begin{array}{c}\text { U. Piluifera dissolve in Cold } \\
\text { and Hot water }\end{array}$ & 1 & $0.02 \pm 22.3 d$ & 67.5 & 32.5 & $2.8 \pm 46.6 \mathrm{~d}$ & 62.9 & 37.1 & $4.1 \pm 68.9 \mathrm{~d}$ & 64.3 & 35.7 \\
\hline
\end{tabular}

Table 6: Effect of IC50 of E. arvense and U. Piluifera dissolve in Cold \& Hot water on the amount of nucleic acid ( $\mu \mathrm{g} / \mathrm{ml})$ of $L$. tropica promastigotes at log-phase (96 hrs)

promastigotes (IC50) was $1.0 \mu \mathrm{g} / \mathrm{ml}$, whereas at logarithmic phase $(96$ hrs of cultivation).

The number of $L$. tropica. promastigotes decreased gradually for 2.5 from 40.5 after 24 hour to 18.7 after 72 hour and to 12.1 after 96 hrs of cultivation.

The Equisetum arvense and U. Piluifera dissolve in Cold and Hot water found to cause reduction in protein content in Leishmania tropica. promastigotes that were treated with IC50 of the tested extracts (Table 4$)$. The extracts found to reduce to $(7.8 \%),(14.8 \%)$ and $(20.9 \%)$ respectively at log-phase (96 hrs),Moreover, this study show the effect of E. arvense and U. Piluifera dissolve in Cold and Hot water on total Carbohydrates of $L$. tropica. promastigotes (Table 5), The table shows that the carbohydrates rate L. tropica. decreased to $(7.6 \%),(16.8 \%)$ and (18.2\%) respectively by IC50 concentrations of the extract at log-phase (96 hrs).

Table 6 includes the result of effect of E. arvense and U. Piluifera dissolve in Cold and Hot water on the total of Nucleic acid (DNA and RNA) of $L$. tropica. promastigotes at log-phase (96 hrs), the total (DNA and RNA) reduced to (9.1\%) for DNA, (23.5\%) for RNA and (25.3\%) for total nucleic acid when treated with IC50 of the E. arvense extract, and reduced to (30.4\%) DNA, (32.5\%) RNA and (31.8\%) total nucleic acid when treated with IC50 of the U. Piluifera dissolve in cold water, moreover, the IC50 of $U$. Piluifera dissolve in Hot water reduced of the DNA (32.5\%), RNA (37.1\%) and (35.7\%) of total nuclide acid with IC50 extract at log-phase (96 hrs).

\section{Conclusion}

Therapeutic evaluations for medicinal plants are essential because of the growing interests in alternative therapies and the use of natural products. Natural products have potential in the search for new and selective agents for the treatment of important tropical diseases caused by protozoans [14].

Equisetum arvense is a plant with wide prospectus. In folk medicine, Equisetum arvense is used for, pulmonary and gastric haemorrhages, for brittle fingernails and loss of hair, for rheumatic diseases, gout, poorly healing wounds and ulcers, swelling and fractures and for frostbit. The plant is reported to contain a number flavonoids, alkaloids, minerals, phenolic petrosins, triterpenoids, saponins, phytosterols [15], moreover, Urtica pilulifera have a long history of use in the home as a herbal remedy. The whole plant is antiasthmatic, diuretic, it is also used to treat anaemia, haemorrhoids, rheumatism and skin complaints, especially eczema. It is used in the treatment of ailments such as bites and stings, burn and hives [16].

The Equisetum arvense and Urtica pilulifera extracts dissolved in cold and hot water were tested for their antileishmanial properties in vitro. The significant inhibitory effect of extracts on the growth of Leishmania tropica. promastigotes may be elucidated by different 
reasons. May be these plants have poisoning effect on the promastigotes because the Equisetum arvense contain a number of flavonoids and like nicotine and many active materials, as well as, the Urtica pilulifera contain a number of amines, minerals like Calcium, Potassium and may be contain lignans $[17,18]$.

On the other hand, The Equisetum arvense and Urtica pilulifera extracts effected on total Protein and nucleic acids of treated promastigotes.

Proteins of protozoan cells have similar characters of those in higher organism [19], many antiprotozoan agents affect metabolism of proteins and nucleic acids of the target organism like ketokonazole, allopurinol, chloropromazine, ethidium, dihudroemitine and soramine $[20,21]$, these results of this study the result of effect of effects of crude alkaloids isolated from Peganum harmala seeds on the growth and metabolism of Leishmania tropica. promastigotes [22], Furthermore, some plant extracts that contain alkaloids have been found to have inhibitory effects on lieshmania metabolism, for example, [23] and result of $[24,25]$ revealed that treating of ehrlich ascites tumor cells with Daphnoretin compound extract effect on total protein of treated cells, as well as, the Ketoconazole drag reduce the total protein of treated Leishmania tropica and Lieshmania donovani promastigotes [26].

The nucleic acids ( DNA, RNA) are very important structure in the living cell, in this study may be the effect of Equisetum arvense and Urtica pilulifera extracts on Leishmania tropica, promastigotes because this extract includes many active compounds can effect on total nucleic acids of Leishmania tropica. promastigotes or effect on the enzymes of parasite [27].

This study includes the effect of IC50 of Equisetum arvense and Urtica pilulifera extracts on energy metabolism (carbohydrate content) of Leishmania promastegotes in vitro.

All the parasites has carbohydrates on the serves of the cell membrane [28], the result show no more effect of Equisetum arvense and Urtica pilulifera extracts on total carbohydrates of Leishmania tropica. Promastigotes, this results show the cell membrane become mechanical barrier between the extract and parasite [23,24].

Present study concludes that Equisetum arvense and Urtica pilulifera extracts show a promising in vitro antilieshmanial activity and can be considered as new lead structures in the search for novel antilieshmanial drug. Therefore, there is a need for investigation about the efficacy of Equisetum arvense and Urtica pilulifera extracts as antilieshmaneal agents in vivo (in animals) to determine therapeutic indices of such compounds.

\section{References}

1. Ying MA, Dian-mei LU, Xia-jun LU, Lin L, Xiao-su HU (2004) Activity of dihydroartemisinin against Leishmania donovani both in vitro and vivo. Chinese Med J 117: 1271-1273.

2. De Carvalho PB, Ferreira El (2001) Leishmaniasis phytotherapy. Nature's leadership against an ancient disease. Fitoterapia 72: 599-618.

3. Rocha LG, Almeida JR, Macedo RO, Barbosa-Filho JM (2005) A review of natural products with antileishmanial activity. Phytomedicine 12: 514-535.

4. Balana FR, Reguera R, Cubria JC, Ordonez D (1998) The pharmacology of leishmaniasis. Gen Pharmacol 30: 435-443.

5. Camacho (2000) M.d.R Camacho, S.L Croft, J.D Phillipson Natural products as sources of antiprotozoal drugs Current Opinion in Anti-infective Investigational Drugs 2: 47-62.

6. AL-Jeboori TI, Evans DA (1980) Leishmania spp. In: Iraq. Electrophoretic isoenzyme pattern II. Cuteneous leishmaniasis. Trans Roy Soc Trop Med Hyg 74: 178-184.

7. Tobie EJ, Brand TV, Mehlman B (1950) Cultural and Physiological observation on Trypanosoma rhodesiense and Trypanosoma gambeinse. J Parasitol 36: 48-54.

8. Riose JL, Recio MC, Villar A (1987) Antimicrobial activity of selected plants employed in the Spanish Mediterranean area. J Ethnopharmacol 21: 139-152.

9. Essawi T, Srour M (2000) Screening of some Palestinian medicinal plants for antibacterial activity. Ethnopharmacol 70: 343-349.

10. Lowry OH, Rosebrough NJ, Farr AL, Randall RJ (1951) J Biol Chem 193: 265 (The original method).

11. Herbert D, Philips PJ, Stance RE (1971) In Methods in Microbiology (5B). (ed Norris) J.R. and Ribbons D. W. Academic Press. London and New York. 241245.

12. Schneider WC (1957) Determination of nucleic acids in tissues by pentose analysis In: Methods in Enzymology, Academic Press, New York 111: 515-517.

13. Duncan DB (1955) Multiple range and multiple $F$ tests. Biometrics 11: 1-42.

14. Wright CW, Phillipson JD (1990) Natural products and the development of selective antiprotozoal drugs. Phytother. Res. 4: 127-139.

15. Sandhu NS, Chopra D, Kaur S (2010) Equietum arvense: pharmacology and phytochemistry-Res. 3(3).

16. http://www.naturalmedicinalherbs.net/herbs/u/urtica-pilulifera=roman-nettle php

17. Akbay P, Basaran AA, Undegar U, Basaran N (2003) In vitro immunodulatory activity of flavonoid glycoside from urtica dioica L. Phytother Res 17: 34-37.

18. Morrisville PA (2005) Horsetail, Viable Herbal Solution. Web Navigation Panel.

19. Bryant C, Behm CA, Howell MJ (1989) Biochemical Adaptation in Parasites Energy metabolism, Chapman and Hall, London, UK.

20. Hassan HF (1979) Studies on thymidine nucleotide metabolism in Leishmania MSc. Thesis, College of Science, Mosul Unive Iraq.

21. AL-Healy HL (2000) Effect of chloropromazine on growth and metabolism on promastigote forms of Leishmania parasite. M.Sc. Thesis, College of Science, Mosul University.

22. AL-Hammoshi MH (2011) Effects of Crude Alkaloids Isolated from Peganum harmala Seeds on the Growth and Metabolism of Leishmania tropica Promastigotes. J Raf Sci 22: 17-32.

23. AL-Khan HJ (2001) Effect of aqueous extracts of Capparis spinosa and Citrullus colocynthis plants on growth and metabolism of Leishmania major promastigotes in vitro. Ph.D. Thesis, College of Science, Mosul University, Iraq.

24. AL-Jubouri SA (2005) Effect of aqueous extracts of Nerium oleander and Metia azedarach on growth and metabolism of Leishmania tropica promastigotes in vitro.M.Sc. Thesis, College of Science, Mosul University, Iraq

25. Hall LH, Tagahave K, Lee KH (1982) Antitumor agents LIII: The effect of daphnoretin on nucleic acid and protein synthesis of ehrlich tumor cell. $\mathrm{J}$ farm acent Sci 71: 741-744.

26. AL-Chalabi KA, AL-Zahawi SM (1993) Effect of ketoconazole on growth, nucliecacid and protein content of Leishmania tropica and Leishmania donovani promastigotes. Mu'tah. J Res Stud 8: 111-122.

27. Katzung BC (1989) Chemotherapeuties Drugs. In Basic and Clinical Pharmacology, $4^{\text {th }}$ ed., Prentice-Hall International Inc.

28. Muskus C, Segura I, Oddone R, Turcom SJ, Leiby DA, et al. (1997) Carbohydrate and LPG expression in Leishmania viannia subgenus. J Parasitol 83: 671-678. 